\title{
A Predictive Research on the Posttraumatic Improvement of Emergency Health Employees
}

\author{
Selahattin Avşarolu ${ }^{1}$ \\ ${ }^{1}$ Necmettin Erbakan University/Kyrgyz-Turkish Manas University, Bishkek, Kyrgyztan \\ Correspondence: Selahattin Avşaroğlu, Department of Educational Sciences, Faculty of Literature, \\ Kyrgyz-Turkish Manas University Bishkek, Kyrgyztan. E-mail: seloavsar@gmail.com
}

Received: January 18, 2019

doi:10.5539/ies.v12n6p94
Accepted: February 26, 2019 Online Published: May 29, 2019

URL: https://doi.org/10.5539/ies.v12n6p94

\begin{abstract}
Traumatic incidents are defined as despair people are in when they face fears, weaknesses and vulnerabilities. The purpose of the present research is determining the mental problems faced by emergency health workers while performing their jobs and how they deal with these problems. For this purpose, "The Hopelessness Scale, Locus of Control Scale, Problem Solving Inventory, Multidimensional Scale of Perceived Social Support, Post Traumatic Growth Inventory, Peritraumatic Dissociative Experiences Questionnaire, The Posttraumatic Diagnostic Scale and Beck Depression Inventory were used as data collection tools. The present research was designed in accordance with general screening model, which is a descriptive research method. With this model, how the independent variable affected the dependent variable was investigated and the regression analysis was conducted for the relationship between the variables. The research was carried out on the employees of the Department of Emergency Health Services in Erzincan and data were collected from 400 emergency health workers. The statistical analysis of the data was done by SPSS 20.00 package program and .05 was taken as the significance level. According to the regression analysis results hopelessness, negative effects of events on life, social support and dissociation were significantly related with stress symptoms and depressive mood levels. It was found that the effects of event and dissociation predict posttraumatic stress symptoms positively; and social support negatively. It was observed that hopelessness and post-traumatic stress symptoms predicted the level of depression positively and social support negatively. According to the findings of the research, it was recommended that psychosocial support units may be useful in emergency health services and psycho-education and psychological counseling services provided by the psychosocial unit can be useful for the stress, posttraumatic stress disorder and other problems that may be experienced.
\end{abstract}

Keywords: trauma, traumatic stress, post-traumatic stress, healthcare workers, emergency health services

\section{Introduction}

Traumatic incidents are when people face their fears, helplessness, weaknesses, vulnerabilities, and are deeply affected. According to DSM V (2013) trauma refers to exposure to death, serious injuries or sexual assault or threats from one or more ways listed below: (1) experiencing traumatic events directly, (2) personally witnessing while the events happen to others, (3) learning that a close family member or close friend experienced traumatic events-in the case that when a family member or a friend experiences death or death risk, the incidents involve violence or result from accidents, (4) repeated or excessive exposure to disturbing details of traumatic events. Although this definition is useful, the requirement that trauma is limited to "death, serious injury, or exposure to sexual violence or threat" has been criticized on the grounds that many events may be traumatic, even if they do not involve death or injury. The previous DSM III-R (APA, 1987) described threats to psychological integrity as a valid form of trauma. The DSM V undoubtedly underestimate the prevalence of actual trauma in the general population, because it does not identify events that aren't life-threatening, for example, excessive emotional abuse, significant loss or separation, humiliation or humiliation, sexual experience with compulsion (not physical violence) as trauma. In addition, the criteria for post-traumatic stress disorder (Brewin \& Holmes, 2003) and the diagnosis of acute stress disorder (Horowitz, Wilner, \& Alvarez, 1979) are prerequisites, some people who suffer from significant post-traumatic stress are less likely to be diagnosed with stress disorder (Baysak, 2010; Briere \& Scott, 2016; Cohen \& Murch, 1996).

Traumatic incidents (Kahil, 2016) lead individuals to severe fear and helplessness (Bryant \& Harvey, 2003). 
During the traumatic incident, one is left desperate by an irresistible force (Koren, Arnon, \& Klein, 1999). Traumatic incidents paralyze the person's sense of control, linking and meaning attribution skills (Türksoy, 2003). The person who suffers from paralysis of coping skills starts to have problems and difficulty in adapting to normal life. The normal reactions to the unusual situation in the early period are considered as an attempt to adapt to this situation. According to DSM-V, these troubles indicate that the person has experienced a real death or death threat or witnessed such an event. They are overwhelmed by fear, helplessness or horror. The traumatic incident was recalled unavoidably, there was a constant avoidance of stimuli accompanied by a traumatic event and a decrease in general response to stimuli accompanied by a traumatic event. Symptoms of increased stimulation were observed after the traumatic incident. It is acute stress disorder when lasts at least two days and at most four weeks. These problems lasting longer than one month indicates post-traumatic stress disorder. Symptoms lasting longer than three months indicate chronic posttraumatic stress disorder. The onset of symptoms after six months is defined as delayed post-traumatic stress disorder (DSM V, 2013).

Some occupational groups constantly face the traumatic experiences due to their jobs (Bryant, \& Harvey, 1997). Firefighters (Beaton, Tougas, \& Joly, 1996), mental health professionals, police (Alexander \& Wells, 1991) physicians (Lundin \& Bodegard, 1993) and search and rescue workers (Chang, Lee, Connor, \& Davidson, 2003) are among the occupational groups that face traumatic events due to their profession. Within these types of services, ambulance employees make the first treatment to the people who are under threat due to their duties and transfer them to the nearest health institution. Among the most frequent traumatic events they face include encountering people exposed to man-made attacks, such as child deaths, social disasters, rape and torture, seeing a dead body or body part, removing the fragmented limbs or corpses from the crash site. It is also easier for healthcare personnel, who witness traumatic incidents while they response to such problems, that they experience problems such as acute stress disorder, posttraumatic stress disorder, major depression, psychosomatic disorders and substance use disorder (Baysak, 2010; Erkaya, 2003).

Employees who provide emergency health care services are one of the groups involved in relief work after such events, even if they are not directly exposed to traumatic events. It is believed that they may have anxiety and depression symptoms towards death due to their jobs. It is an inevitable fact that there is a high probability of personal threat in relief work. There is a direct and continuous witnessing to the traumatic incidents and their effects. Exposure to life-threatening events, responses to save the lives of the victims, and removing seriously injured and inanimate bodies from debris are factors that increase the symptoms of traumatic stress and anxiety among the medical staff providing emergency medicine services (Clark, 1999; Fullerton, Ursan, \& Wang, 2004; North et al., 2002). Individuals' perceptions of the severity of the threat they or others are exposed to are an important determinant for possible reactions that may arise later. The more threatening an individual perceives the incident, the more intense an anxiety they will experience. Employees of this kind should have different skills such as instilling hope (Seber, Dilbaz, Kaptanoğlu, \& Tekin, 1993). Such an approach is very important for social support (Solomon, Mikulincer, \& Avitzur, 1988).

Emergency health service teams often face traumatic deaths due to their professions, while assisting people, who have suffered a catastrophic life threat, in emergency rescue work. These experiences can cause various psychological and psychosocial stress reactions among many emergency rescue workers (Schnurr, Lunney, \& Sengupta, 2004). After such traumatic stresses, psychiatric disorders, such as physical and psychosomatic disorders, depression, and substance use may occur (Joseph, Williams, 2005). In addition, it was reported that alcohol and substance use rates in these individuals were higher than the general population, and in some cases posttraumatic stress disorder may develop (Tedeschi \& Calhoun, 2004). This also may result in burnout. Especially the anxiety and depressive feelings against the death experienced by the health personnel who provide emergency medical services in which traumatic deaths are experienced most and the first responses are given, can affect their psychosocial side negatively and that can make their work lives inefficient. This case is reported to cause health personnel to decrease their interest in the profession (Erkaya, 2003; Sönmez, 2006). Therefore, the importance of social support in addition to preventive psychological services increases even more.

The present research aims at determining the mental problems experienced by emergency health workers and how they deal with these problems. The prevalence of occupational traumatic events due to the working conditions of the emergency team, the frequency of encountering traumatic events and witnessing traumatic events affect the employees at various levels. The sub-objectives developed for the present research, which aims to determine the relationship between various variables, are presented below.

1) Are the results of the first and second regression analysis in which the post-traumatic stress diagnostic scale is dependent variable, related significantly? 
2) Are the results of the third and fourth regression analysis in which the Beck depression scale is dependent variable, related significantly?

3) Are the results of the fifth and sixth regression analysis in which the post-traumatic growth scale is dependent variable, related significantly?

\section{Method}

The present research employed general screening model, which is a descriptive research method. How the independent variable affects the dependent variable is studied with this model. The general screening model is the screening organizations conducted on the whole of the universe or a group, sample or sample to be taken from a universe of a large number of elements, in order to reach a general judgment about the universe (Karasar, 2013). The present research analyzes the relationship between despair, locus of control, problem solving, perceived social support, post-traumatic stress, post-traumatic dissociative experience and depression levels among emergency health care employees and tries to generalize it to the universe.

\subsection{Group}

The research group of the present research consists of emergency health employees who worked as allied health personnel of Erzincan Province Emergency Health Services Directorate.

\subsection{Data Collection Tools}

Within the scope of the present research, various psychological scales have been used to measure the psychological variables presented in the above sections. In the present research, diagnostic categories such as Acute Stress Disorder, Posttraumatic Stress Disorder, Dissociative Disorder are not used. The various symptoms following the trauma are measured as continuous variables by means of the scales. Therefore, it is investigated not whether participants who present symptoms of post-traumatic stress have any psychological disorders, but how they respond. The psychological variables measured by the scales and their scoring directions are presented in Table 2.

Table 1. Psychological variables measured by the scales and scoring directions

\begin{tabular}{ccc}
\hline Scale & Measured Psychological Variable & The Meaning of High Scores \\
\hline $\begin{array}{c}\text { Incident Severity Sub-Scale } \\
\text { Incident Effect Sub-scale } \\
\text { Post-traumatic Stress Symptoms }\end{array}$ & $\begin{array}{c}\text { Severity of the Traumatic Incident } \\
\text { The effect of the traumatic incident on life }\end{array}$ & $\begin{array}{c}\text { High severity } \\
\text { High effect }\end{array}$ \\
Sub-scale & Level of post-traumatic stress symptoms & High level of symptoms \\
Hopelessness Scale & Negative expectations for the future & High level of hopelessness \\
Tocus of Control Scale & The position of the generalized control expectations on the individual is prone to \\
dimension of internality- externality & external control locus \\
Problem Solving Inventory & Self-perception of problem solving skills & Negative self-perception \\
Perceived Social Support Scale & Perceived social support from family, friends and someone & High perceived social support \\
Beck Depression Inventory & special & High depressive mood level \\
Post-traumatic growth scale & Depressive mood level & High post-traumatic growth level \\
Peri-traumatic Dissociative & Post-traumatic growth level & High level of dissociation \\
Experiences Questionnaire $-\mathrm{R}$ & Level of dissociation during the incident &
\end{tabular}

The psychological variables measured by the scales that the participants answered and the average scores of the scoring from all scales are presented in Table 2. 
Table 2. Participants' scores from the scales

\begin{tabular}{|c|c|c|}
\hline Scale & $\begin{array}{c}\text { Average (SD) } \\
\text { Range }(\mathrm{N}=400)\end{array}$ & Possible highest score \\
\hline Incident Severity & $\begin{array}{c}2.48(1.54) \\
0-6\end{array}$ & 6 \\
\hline Incident Effect & $\begin{array}{c}2.34(2.48) \\
0-9\end{array}$ & 9 \\
\hline Post-traumatic growth & $\begin{array}{c}37.57(25.45) \\
0-105\end{array}$ & 105 \\
\hline Dissociation & $\begin{array}{c}6.11(6.57) \\
0-32\end{array}$ & 32 \\
\hline Hopelessness & $\begin{array}{c}4.15(4.11) \\
0-20\end{array}$ & 20 \\
\hline Social Support & $\begin{array}{c}66.80(12.38) \\
12-84\end{array}$ & 84 \\
\hline $\begin{array}{c}\text { Post-traumatic Stress Sy } \\
\text { mptoms }\end{array}$ & $\begin{array}{c}8.18(8.87) \\
0-51\end{array}$ & 51 \\
\hline Locus of Control & $\begin{array}{c}9.89(3.34) \\
2-21\end{array}$ & 23 \\
\hline Problem Solving & $\begin{array}{c}84.29(19.96) \\
37-154\end{array}$ & 210 \\
\hline Beck Depression Inventory & $\begin{array}{c}8.24(7.71) \\
0-53\end{array}$ & 63 \\
\hline
\end{tabular}

\subsubsection{The Hopelessness Scale}

The Hopelessness Scale is a 20 -item self-report scale developed by Beck, Lesker and Trexler (1974) to measure the negative expectations for the future of individuals. It can be administered on adolescents and adults. Participants respond as "yes" for the statements that fit themselves, and "no" for the ones that don't. Eleven of the items $(2,4,7,9,11,12,14,16,17,18,20)$ scores as 1 point for answer "yes", and nine $(1,3,5,6,8,10,13$, $15,19)$ are scored for answer "no". Score range of the scale is $0-20$. Higher scores indicate high levels of hopelessness. Internal consistency coefficient of the original form of the scale was reported as $\alpha=.93$ (KR-20 method) (Beck, Lesker, \& Trexler, 1974). The correlation of the scale was reported as .74 at hospital sample and as .72 for suicidal patients, and the factor analysis revealed three dimensions (affection, motivational and cognitive aspects of hopelessness) for the scale (Beck, Lesker and Trexler, 1974). Turkish adaptation of the scale was conducted by several researchers (Durak, 1994; Savaşır \& Şahin, 1997; Seber, 1991). These researchers report $\alpha=.86$ and $\alpha=.83$ levels of internal consistency (Cronbach Alpha) (Durak, 1994; Seber, Dilbaz, Kaptanoğlu, \& Tekin, 1993). There have been adequate numbers of studies on the validity of the scale as well. Its correlation with Beck Depression Inventory was reported as .65 by Seber (1991), and .69 by Durak (1994).

\subsubsection{Locus of Control Scale}

Rotter's Internal-External Locus of Control Scale developed by Rotter (1966) is used to determine the position of generalized control expectations on the internal-externality dimension of individuals. Six items $(1,8,14,19$, $24,27)$ of the 29 -item scale cannot be scored as they are slack items. Every item includes sentences forming options "a" and "b". For some of the items $(2,6,7,9,16,17,18,20,21,23,25,29)$ option "a" is scored while for others $(3,4,5,10,11,12,13,15,22,26,28)$ option " $b$ " is scored as 1 point. The total range of the scale is between 0-23. Higher scores indicate external locus of control (Rotter, 1966). Studies using test-retest method report that the reliability coefficient of the scale ranges between .49 and .83 (Savaşır \& Şahin, 1997). Previous studies on the validity of the scale state that factor structure of the scale represents two dimensions. Correlation coefficients with other locus of control scales are reported vary between .25 and .55 (Savaşır \& Şahin, 1997). Locus of Control Scale was adapted to Turkish by Dağ (1991). Internal consistency coefficient was reported as $\alpha=.71$. Test-retest method reliability coefficient was reported as .83 . The factor analysis was reported to produce similar results with the original form of the scale (Dağ, 2002).

\subsubsection{Problem Solving Inventory}

Problem Solving Inventory, Form-A is a scale developed by Heppner and Petersen (1982) to measure individuals' self-perceptions of their problem solving skills. It can be administered on the adolescents and adults. 
The scale consists of 35 items scored on a 6 point likert type scale. The participants are asked how frequently they behave as stated in scale items. The answered are scored between 1 and 6 points. Some items $(9,22,29)$ are not scored. Some items $(1,2,3,4,11,13,14,15,17,21,25,26,30,34)$ are scored reversely. The score range of the scale is $32-192$. Higher scores from the scale indicate that the participant perceives themselves as inadequate in problem solving skills. The study developing the original form of the scale (Heppner \& Petersen, 1982) reports its internal consistency coefficient as $\alpha=.90$. According test-retest method, reliability coefficients of the subscales range between .83 and .89 . The total score from the scale is reported to correlate with problem-solving level at -.46 level, and with satisfaction from problem solving skills at -.42 level. Factor analysis produced three sub-dimensions: confidence in problem solving skill, approach-avoidance and personal control. Internal consistency coefficients of these sub-dimensions were reported as $.85, .84$ and .72 respectively (Heppner \& Petersen, 1982). Problem Solving Inventory was adapted to Turkish by Şahin, Şahin and Heppner (1993). Internal consistency coefficient of the Turkish form was reported as $\alpha=.88$. The correlation of the scale with Beck Depression Inventory was reported as .33; and as .45 with State-Trait Anxiety Inventory-Trait Anxiety subscale (STAI-T). Factor analysis was reported to produce six sub-dimensions: hasty approach, thoughtful approach, avoidant approach, evaluative approach, self-confident approach and planned approach. Internal consistency of these dimensions were reported respectively as $\alpha=.78, \alpha=.76, \alpha=.74, \alpha=.69, \alpha=.64$ and $\alpha=.59$ (Şahin, Şahin \& Heppner, 1993).

\subsubsection{Multidimensional Scale of Perceived Social Support}

Multidimensional Scale of Perceived Social Support developed by Zimet, Dahlen, Zimet, and Farley (1988) consists of 12 likert-type items. The participants score items related to perceived social support from three differed sources (family, friend, someone special) on a scale of 1 to 7 . The range of the scale is 12-84. Higher scored indicate higher perceived social support. The scale was adapted to Turkish by Eker and Arkar (1995). The researchers reported that the internal consistency coefficient of the scale ranged from $\alpha=.77$ to $\alpha=.88$ in their study on different sample groups. The internal consistency coefficients of the subscales vary between $\alpha=.78$ and $\alpha=.91$. The factor structure of the scale is similar to the original. As in the original scale, the items $1,2,5,10$, are loaded on someone special, items 3, 4, 8, 11 are loaded with family, items 6, 7, 9 and 12 are loaded on the friend sub-factor. The correlation coefficients of the total scores obtained from different samples with Beck Depression Inventory and State-Trait Anxiety Inventory (STAI) indicate a sufficient level of criterion validity.

\subsubsection{Posttraumatic Growth Inventory}

Posttraumatic Growth Inventory developed by Tedeschi and Calhoun (1996) is a 21 -item scale. The scale is a Likert-type scale scored between 0-5. The range of the scale is $0-105$. Higher scores from the scale indicate higher level of growth after traumatic incident. The internal consistency of the scale was reported as $\alpha=.90$ in the study that developed the original scale (Tedeschi and Calhoun, 1996). Internal consistency of the sub-scales vary between $\alpha=.67$ and $\alpha=.85$. Correlation coefficient was reported as .71 in the study conducted for test-retest validity. Conducted factor analysis presented five sub-dimensions: positive in interpersonal relations, changes in the perception of self, understanding the value of life, realizing new options, development in belief system. The scale was adapted to Turkish by Dürü (2006). The reliability of Posttraumatic Growth Inventory was tested with Cronbach Alpha method. Internal consistency coefficient was calculated as $\alpha=.93$. Conducted pre-study showed that the correlation of Posttraumatic Growth Inventory was .23 with Dissociative Experiences Questionnaire and .26 with Impact of Event Scale. Additionally, the present research found that the coefficient of the correlation of the scale with The Posttraumatic Diagnostic Scale was .21, which is significant $(p=.06)$. Construct validity of the scale was tested with factor analysis method. In the five-factor analysis, which was considered as the most appropriate among various analyses, 15 of the 21 items are loaded on the factors defined in the original scale. This five-factor analysis explains the $67.84 \%$ of the variance (Dürü, 2006).

\subsubsection{Peritraumatic Dissociative Experiences Questionnaire- $\mathrm{R}$}

The first form of the 10-item Peritraumatic Dissociative Experiences Questionnaire was developed by Marmar, Weiss, and Metzler (1997). However, due to some problems experienced in administration, it was reviewed and the number of items were decreased to eight (Marshall, Orlando, Jaycox, Foy and Belzberg, 2002). The scale includes severity of the decomposition experience, time perception, depersonalization and derealization experiences during the traumatic event. The participants are expected to respond to the level of experience defined in each article on a 5-point Likert-type scale. The original form of the scale is reported to have a high-level of internal consistency $(\alpha=.80)$, acceptable criterion validity and discrimination power. For the reviewed form, test-retest validity coefficient was reported as .85 and internal consistency was reported as $\alpha=.85$ (Marshall, Orlando, Jaycox, Foy, \& Belzberg, 2002). The scale was adapted to Turkish by Dürü (2006). Internal 
consistency coefficient was calculated as $\alpha=0.84$ for all scale items, and item-total test correlation coefficients calculated for the scale items range between .49 and .61. In order to test the validity of the scale, its correlation with several other scales was calculated. The correlation coefficient of the scale was reported as .34 with Beck Anxiety Inventory, .43 with Beck Depression Inventory and .50 with Short Symptoms Inventory. That all coefficients were on the expected direction and statistically significant are important indicators of the validity of the scale (Dürü, 2006).

\subsubsection{The Posttraumatic Diagnostic Scale}

The Posttraumatic Diagnostic Scale consisting of 50 self-report items was developed by Foa, Cashman, Jaycox, and Perry (1997) in order to determine post-traumatic stress disorder. The scale can be administered on 18-65 year-old individuals. The original form of the scale consists of four parts. The first part is for defining the type of the traumatic incident (natural disaster, accident, war, rape, etc.) experienced by the participant. The second part aims at defining the incident that most affected the participant if there is more than one traumatic incident. This part also includes 6 items responded as yes-no, aiming at defining the severity of the traumatic incident. These 6 items aiming at defining the severity of the traumatic incident were also used to define the severity of the traumatic incident for the present research, and it is called as "incident severity sub-scale". More "yes" responses indicate high severity. The third part of the scale consists of a 17-item sub-scale evaluating the post-traumatic symptoms. These 17 items are called as "post-traumatic stress symptoms sub-scale" within the present research and used to define the level of the trauma symptoms. Post-traumatic stress symptoms sub-scale is a likert type scale on a 0-3 point scoring DSM-IV (APA, 1994). Range of the sub-scale is 0-51. Higher score indicate that the participant was affected from the incident negatively and presents post-traumatic stress symptoms. The fourth and last part of the scale consists of 9 items responded as "yes-no" aiming at defining the effects of the traumatic incident on the participants' lives. These 9 items are used to define the effects of the incident within the scope of the present research, and called as "Incident Effect Sub-scale". The internal consistency of the 17 items used in the present research in order to measure the severity of the trauma symptoms was reported as $\alpha=0.92$ and the test-retest reliability coefficient as .83 (Foa, Cashman, Jaycox, \& Perry, 1997). The scale was reported to distinguish the individuals who were diagnosed as TSSB with another criteria (structures clinical and diagnostic interview, SCDI) at $82 \%$ level (sensitivity); and the individuals not diagnosed with TSSB at $76 \%$ (specificity), and have acceptable correlation coefficients with some scales used as criteria (Foa, Cashman, Jaycox \& Perry, 1997). The internal consistency of 17 items aiming to measure symptom level was calculates for scale validity. Cronbach Alpha coefficient for all items was reported as $\alpha=.93$ and item-total test correlation coefficients ranged between 0.39 and 0.82 . The validity of the 17 -item post-traumatic stress symptoms sub-scale was tested in two ways. The scale is known to have been designed in order to measure the severity of the disorders caused by post-traumatic stress and to meet DSM-IV (APA, 1994) criteria of post-traumatic stress disorder; B (re-live), C (avoidance), and D (over-stimulation). According to the results of this analyses, all items but $2\left(6^{\text {th }}\right.$ and $7^{\text {th }}$ items) were loaded on the factors they should be theoretically. These two items were loaded on "over-irritation" factor, while they should be on "re-live" factor (Işıkl1, 2006; Kahil, 2016).

\subsubsection{Beck Depression Inventory}

Beck Depression Inventory developed by Beck, Ward, Mendelson, Mock, and Erbaugh (1961) in order to evaluate the severity of the depressive symptoms presented within the last week consists of 21 self-report items, and it was based on clinical observations and data instead of a theoretical opinion. These 21 items are scored between 0-3 points. The score from the inventory indicate the severity of the depression as well. It was adapted to Turkish by Hisli Şahin (1988) and has been used frequently in many studies conducted in Turkey.

\section{Results}

In accordance with the purpose and sub-objectives of the present research, the total of six regression analyses were conducted for three defined dependent variables for each gender in order to measure how employees are affected from the traumatic incidents they encounter.

\subsection{Results of First and Second Regression Analyses for Post-Traumatic Stress Symptoms Scale as the Dependent Variable}

Incident Effect Sub-scale, Incident Severity Sub-scale, Peri-traumatic Dissociative Experiences Questionnaire-R, Hopelessness Scale, Problem Solving Inventory, Locus of Control Scale and Perceived Social Support Scale were included as independent variables in the first and second regression analyses, in which Post-traumatic Stress Symptoms Scale was used as the dependent variable. First regression analysis was conducted on female participants while second was on male participants. 
Table 3. Results of the first regression analysis on female participants for post-traumatic stress symptoms scale as the dependent variable

\begin{tabular}{ccccc}
\cline { 2 - 4 } & Model & Variable & Beta & $\underline{\mathrm{t}}$ \\
\cline { 2 - 5 } & & Incident severity & .080 & 1.127 \\
& Incident effect & .209 & $2.907^{*}$ \\
& Dissociation & .276 & $3.939^{* *}$ \\
1 & Hopelessness & .233 & $3.186^{*}$ \\
& & Locus of control & .001 & .014 \\
& & Problem solving & .021 & .294 \\
& & Social support & -.092 & -1.132 \\
\hline
\end{tabular}

$* \mathrm{p}<.01, * * \mathrm{p}<.001$

Table 3 presents the results of the first regression analysis. In the first regression analysis on female participants with the post-traumatic stress symptoms as the dependent variable, it was calculated as $\mathrm{R}=.556$ ( $\mathrm{F}(7$, 177) $=11.320, \mathrm{p}<.001)$ after all variables were block included in the analysis. It was found that incident effect $(\mathrm{t}=2.907, \mathrm{p}<.01)$, dissociation $(\mathrm{t}=3.939, \mathrm{p}<.001)$ and hopelessness $(\mathrm{t}=3.186, \mathrm{p}<.01)$ predicted post-traumatic stress symptoms positively. On the other hand, incident severity, locus of control, problem solving and social support variables didn't predict post-traumatic stress symptoms at a significant level.

Table 4. Results of the second regression analysis on male participants for post-traumatic stress symptoms scale as the dependent variable

\begin{tabular}{ccccc}
\cline { 2 - 4 } & Model & Variable & Beta & $\underline{\mathrm{t}}$ \\
\cline { 2 - 5 } & & Incident severity & -.064 & -.989 \\
& Incident effect & .279 & $.3 .941^{*}$ \\
& & Dissociation & .284 & $4.172 *$ \\
& 1 & Hopelessness & .023 & .332 \\
& & Locus of control & .063 & .962 \\
& & Problem solving & .021 & .328 \\
& & Social support & -.263 & $-4.002 *$ \\
\hline
\end{tabular}

$* \mathrm{p}<.001$.

Table 4 presents the results of the second regression analysis. In the second regression analysis on male participants with the post-traumatic stress symptoms as the dependent variable, it was calculated as $\mathrm{R}=.599$ $(\underline{F}(7,183)=14.602, p<.001)$ after all variables were block included in the analysis. It was found that incident effect $(\mathrm{t}=3.941, \mathrm{p}<.001)$ and dissociation $(\mathrm{t}=4.172, \mathrm{p}<.001)$ predicted post-traumatic stress symptoms positively and social support $(\mathrm{t}=-4.002, \mathrm{p}<.001)$ negatively. On the other hand, incident severity, hopelessness, locus of control, and problem solving variables didn't predict post-traumatic stress symptoms at a significant level.

\subsection{Results of Third and Fourth Regression Analyses for Beck Depression Inventory as the Dependent Variable}

Incident Effect Sub-scale, Incident Severity Sub-scale, Peri-traumatic Dissociative Experiences Questionnaire-R, Posttraumatic Stress Symptoms Scale, Hopelessness Scale, Problem Solving Inventory, Locus of Control Scale and Perceived Social Support Scale were included as independent variables in the third and fourth regression analyses, in which Beck Depression Inventory was used as the dependent variable. Third regression analysis was conducted on female participants while fourth was on male participants. 
Table 5. Results of the third regression analysis on female participants for depression level as the dependent variable

\begin{tabular}{cccc}
\cline { 2 - 4 } Model & Variable & Beta & $\underline{\mathrm{t}}$ \\
\cline { 2 - 4 } & Incident severity & -.033 & -.481 \\
& Incident effect & .061 & .867 \\
& Dissociation & -.001 & -.021 \\
\multirow{2}{*}{1} & Hopelessness & .265 & $3.654^{* *}$ \\
& Locus of control & .028 & .395 \\
& Problem solving & .077 & 1.106 \\
& Social support & -.263 & $-3.866^{* *}$ \\
& Posttraumatic Stress Symptoms & .207 & $2.866^{*}$ \\
\hline
\end{tabular}

$* \mathrm{p}<.01, * * \mathrm{p}<.001$

Table 5 presents the results of the third regression analysis. In the third regression analysis on female participants with the depression levels as the dependent variable, it was calculated as $\mathrm{R}=.603(\underline{\mathrm{F}}(8,176)=12.561, \mathrm{p}<.001)$ after all variables were block included in the analysis. It was found that hopelessness $(\mathrm{t}=3.654, \mathrm{p}<.001)$ and post-traumatic stress symptoms $(\mathrm{t}=2.866, \mathrm{p}<.001)$ predicted depression level positively and social support $(\mathrm{t}=-3.866, \mathrm{p}<.001)$ negatively. On the other hand, incident effect, dissociation, locus of control and problem solving variables didn't predict depression level at a significant level.

Table 6. Results of the fourth regression analysis on male participants for depression level as the dependent variable

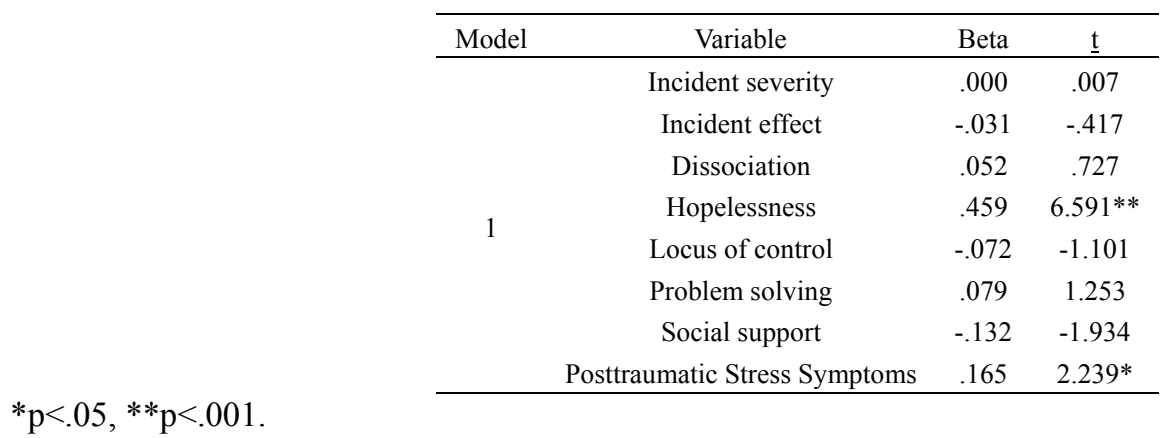

Table 6 presents the results of the fourth regression analysis. In the fourth regression analysis on male participants with the depression levels as the dependent variable, it was calculated as $\mathrm{R}=.608(\underline{\mathrm{F}}(8,182)=13.318$, $\mathrm{p}<.001)$ after all variables were block included in the analysis. It was found that hopelessness $(t=6.591, p<.001)$ and post-traumatic stress symptoms $(\mathrm{t}=2.239, \mathrm{p}<.05)$ predicted depression level positively. Social support had a negative effect, which was almost significant $(\mathrm{p}=.055)$. On the other hand, incident severity, incident effect, dissociation, locus of control and problem solving variables didn't predict depression level at a significant level.

\subsection{Results of Fifth and Sixth Regression Analyses for Posttraumatic Growth Inventory as the Dependent} Variable

Incident Effect Sub-scale, Incident Severity Sub-scale, Peri-traumatic Dissociative Experiences Questionnaire-R, Hopelessness Scale, Problem Solving Inventory, Locus of Control Scale and Perceived Social Support Scale were included as independent variables in the fifth and sixth regression analyses, in which Posttraumatic Growth Inventory was used as the dependent variable. Fifth regression analysis was conducted on female participants while sixth was on male participants. 
Table 7. Results of the fifth regression analysis on female participants for posttraumatic growth as the dependent variable

\begin{tabular}{ccccc}
\cline { 2 - 4 } & Model & Variable & Beta & $\underline{\mathrm{t}}$ \\
\cline { 2 - 5 } & & Incident severity & .060 & .752 \\
& Incident effect & .214 & $2.655^{*}$ \\
& Dissociation & .137 & 1.744 \\
& 1 & Hopelessness &.-100 & -.1 .213 \\
& & Locus of control & .020 & .240 \\
& & Problem solving & .123 & 1.527 \\
& & Social support &.-025 & -.315 \\
\hline
\end{tabular}

$* \mathrm{p}<.01$.

Table 7 presents the results of the fifth regression analysis. In the fifth regression analysis on female participants with the posttraumatic growth as the dependent variable, it was calculated as $\mathrm{R}=.359(\underline{\mathrm{F}}(7,177)=3.734, \mathrm{p}<.01)$ after all variables were block included in the analysis. It was found that incident effect $(\mathrm{t}=2.655, \mathrm{p}<.01)$ predicted posttraumatic growth positively. On the other hand, incident severity, dissociation, hopelessness, locus of control and problem solving and social support variables didn't predict posttraumatic growth at a significant level.

Table 8. Results of the sixth regression analysis on male participants for posttraumatic growth as the dependent variable

\begin{tabular}{ccccc}
\cline { 2 - 4 } & Model & Variable & Beta & $\underline{\underline{\mathrm{t}}}$ \\
\cline { 2 - 5 } & & Incident severity & -.132 & -.132 \\
& Incident effect & .346 & $4.266^{*}$ \\
& & Dissociation & .107 & 1.370 \\
& 1 & Hopelessness & .010 & .128 \\
& & Locus of control & -.073 & -.973 \\
& & Problem solving & .033 & .447 \\
& & Social support & -.020 & -.266 \\
\hline
\end{tabular}

$* \mathrm{p}<.001$.

Table 8 presents the results of the sixth regression analysis. In the sixth regression analysis on male participants with the posttraumatic growth as the dependent variable, it was calculated as $\mathrm{R}=.396(\underline{\mathrm{F}}(7,183)=4.876, \mathrm{p}<.001)$ after all variables were block included in the analysis. It was found that incident effect $(t=4.266, p<.001)$ predicted posttraumatic growth positively. On the other hand, incident severity, dissociation, hopelessness, locus of control and problem solving and social support variables didn't predict posttraumatic growth at a significant level.

\section{Discussion}

According to research data, health employees face many traumatic experiences due to their jobs and witness traumatic experiences. Facing the traumatic experience at the primary level and witnessing the traumatic experience, as well as the workload, the uncertainty of the roles, the expectations of the employees, the inadequacy of the job opportunities, cause the health workers to feel exhausted.

Emergency employees face many problems arising from the nature of their job and their work pattern. The patients they deal with experiencing excessive pain and fear may cause similar pain and fear among the health worker who responds, or may cause an employee to remember an event in the past (Taylor, Kuch, Koch, Crockett, \& Passey, 1998; Sabin-Farrell \& Turpin, 2003). Alexander and Klein (2001), reported in their study that about one third of the employees had a high level of general psychopathology, post-traumatic stress reactions and burnout symptoms. Hyman (2004), who investigated the effects of perceived social support and traumatic stress symptoms among emergency workers, found a relationship between trauma history and the level of intrusive thoughts in the last five years. The healing characteristic of social support is emphasized and it should be provided systematically (Dirkzwager, Bramsen, \& van der Ploeg, 2003). Jonsson, Jasmine, Kozak, and Johnson (2008), who investigated the post-traumatic stress disorder among ambulance workers, reported that $62 \%$ of ambulance employees had a traumatic experience before. This means that similar traumatic events were 
experienced in their previous experiences or professionally encountered incidents. Cohen, Gagin, and Peled-Avram (2006) reported in their study that $48.2 \%$ of social workers had a high rate of secondary traumatic stress symptoms. In this case, traumatic events can be claimed to trigger secondary traumatic stress symptoms, which leads to another social trauma (Maercker \& Herrle, 2003) and difficult to prevent stresses.

Bride (2007), who studied prevalence of secondary traumatic stress among social service professionals and evaluated the posttraumatic stress disorder among individuals facing secondary trauma in terms of diagnostic criteria, reported that $45.4 \%$ of participants had intrusive thoughts, $25.2 \%$ presented avoidance symptoms, $25.2 \%$ presented over-stimulation symptoms, $20.2 \%$ presented intrusive and avoidance symptoms, $21.6 \%$ presented intrusive and over-stimulation symptoms, $17.4 \%$ presented avoidance and over-stimulation symptoms and $15.2 \%$ presented intrusive, avoidance and over-stimulation symptoms. Kahil (2016) emphasized that professional aid workers experienced more traumatic stress symptoms than voluntary workers. Jonsson \& Halabi (2006) stated that child death was the first among the most disturbing events. This was reported to be followed by rape, death or illness of a family member. In such cases, emergency health workers present symptoms of post-traumatic stress at various levels (Jonsson \& Halabi 2006). Regression analysis conducted in the present research found that hopelessness, negative effects of events on life, social support and dissociation were related to stress symptoms and depressive mood levels. These findings are in agreement with the related literature (Dürü, 2006). It can be claimed that what matters in this case is providing emergency health care employees with preventive and social support (Dirkzwager, Bramsen, \& Ploeg, 2003; Pengilly, \& Dowd, 2000; Reynolds, \& Brewin, 1998; Sarason, Sarason, Pierce, \& Shearin, 1987). Instilling hope is a very effective approach in this process (Seber, Dilbaz, Kaptanoğlu, \& Tekin, 1993).

It is observed that the employees are not only affected negatively by the traumatic incidents they experience posttraumatic growth (Janoff-Bulman, 2004). However, conducted regression analyses showed that preventive variables, such as problem solving skills and social support weren't related with growth, which is an interesting finding. Preventive studies should aim at understanding the function of these variables better and using their functions positively. Previous studies (Dirkzwager, Bramsen, \& van der Ploeg, 2003; Dürü, 2006; Eker \& Arkar, 1995; Karanc1, Alkan, Akşit, Sucuoğlu, \& Balta, 1999) have specifically aimed at putting social support mechanisms in action. It was found that received social support contributed to coping with stress (Pengilly \& Dowd, 2000). Accordingly, more psychosocial support should be provided.

Emergency health workers are expected to experience psychological problems due to their work. Immediately after the incidents, the health care workers experience psychological distress but cannot get enough information about their distress. They are reluctant to share their problems or do not share the situation in order not to affect their teammates' mental health. From this point of view, having psychosocial support units in emergency health services and providing psycho-educational studies on stress, traumatic stress (Lee \& Young, 2001), post-traumatic stress disorder and other problems (Tedeschi \& Calhoun, 2004) will be beneficial (Tedeschi \& Calhoun, 2004). In addition, it can be claimed that informing employees about how the traumatic incidents they face during their professional lives (Harvey, 1996; Solomon, Mikulincer, \& Avitzur, 1988) and what they can do in such cases will contribute to their mental health.

Considering the positions of the employees working in emergency health services, it was found that the command center employees showed more traumatic stress and depression symptoms than the other units. The command center employees quickly evaluate the incoming notifications and direct the related units. This process can be extremely stressful at times and traumatizing according to the nature of the incident, because when the staff of the command center cannot evaluate the event effectively, they receive negative feedback from both the patient and their relatives and their field colleagues. The negative feedback they receive reduces the motivation of the employees. From this point of view, it can be useful for command center employees to conduct psycho-educational studies to deal with difficult situations and other the issues they need.

It is known for health care employees that they have a frequency of encountering traumatic incidents throughout their lives. Their encounter with such traumatic incidents results from their jobs. It is inevitable for such service field employees that they are affected negatively from people who experience trauma. They need to offer them emergency support services and present such skills as instilling hope at the same time. Based on this finding, we can claim that preventive studies should be conducted in Turkey. Developing nationwide mental health policies, extending preventive mental health services, and preventing traumatic experiences can be useful for early response to traumatic experiences. Developing psycho-educational studies on this issue and providing health care employees with social and psychological support can be useful. 


\section{References}

Alexander, D. A., \& Klein, S. (2001). Ambulance personnel and critical incidents: Impact of accident and emergency work on mental health and emotional well-being. British Journal of Psychiatry, 178, 76-81. https://doi.org/10.1192/bjp.178.1.76

Alexander, D. A., \& Wells, A. (1991). Reactions of police officers to body-handling after a major disaster. A before-and-after comparison. British Journal of Psychiatry, 159(4), 547-555. https://doi.org/10.1192/bjp.159.4.547

Baysak, E. (2010). Acil ve yoğun bakım çalışanlarında, travma sonrası stres bozukluğu, stresle başaçıkma tarzları, tükenmişlik ve ilişkili etkenler. Yayınlanmamış tıpta uzmanlık tezi. Gazi Üniversitesi Psikiyatri Anabilim Dal1, Ankara. https://doi.org/10.5152/tjar.2019.82258

Beaton, A. M., Tougas, D., \& Joly, S. (1996). Neosexism among male managers: Is ita matterof numbers? $\begin{array}{llll}\text { Journal of Applied Social } & \text { Psychology, 26(24), }\end{array}$ https://doi.org/10.1111/j.1559-1816.1996.tb01795.x

Beck, A. T., Lesker, D., \& Trexler, L. (1974). The measurement of pessimism: The Hopelessness Scale. Journal of Consulting and Clinical Psychology, 42(6), 861-865. https://doi.org/10.1037/h0037562

Beck, A. T., Ward, C. H., Mendelson, M., Mock, J., \& Erbaugh, J. (1961). An Inventory for measuring depression. Arch Gen Psychiatry, 4, 561-571.

Brewin, C. R., \& Holmes, E. A. (2003). Psychological theories of posttraumatic stress disorder. Clinical Psychology Review, 23, 339-376. https://doi.org/10.1016/s0272-7358(03)00033-3

Bride, B. E. (2007). Prevalence of secondary traum atic stress among social workers. Social Work, 52(1), 63-70. https://doi.org/10.1093/sw/52.1.63

Briere, J. A., \& Scott, C. (2016). Travma terapisinin ilkeleri. Bilgi Üniversitesi Yayınları. İstanbul.

Bryant, R. A., \& Harvey, A. G. (1997). Acute stres disorder: A critical review of diagnostic and theoretical issues. Clinical Psychology Review, 17, 757-773. https://doi.org/10.1016/S0272-7358(97)00052-4

Bryant, R. A., \& Harvey, A. G. (2003). Gender differences in the relationship between acute stress disorder and posttraumatic stress disorder following motor vehicle accidents. Australian and New Zealand Journal of Psychiatry, 37, 226-229. https://doi.org/10.1046/j.1440-1614.2003.01130.x

Chang, L. C., Lee, L., Connor, K. M., \& Davidson, J. R. T. (2003). Spirituality, resilience, and anger in survivors of violent trauma: A community survey. Journal of Traumatic Stress, 16, 487-494. https://doi.org/10.1023/a:1025762512279

Clark, D. M. (1999). Anxiety disorders: Why they persist and how to treat them? Behaviour Research and Therapy, 37, 5-27. https://doi.org/10.1016/S0005-7967(99)00048-0

Cohen, M., Gagin, R., \& Peled-Avram, M. (2006). Multiple terrorist attacks: Compassion fatigue in Israeli social workers. Traumatology, 12(4), 293-301. https://doi.org/10.1177/1534765606297820

Dağ, İ. (1991). Rotter'in iç-dış kontrol odağı ölçeği'nin üniversite öğrencileri için güvenirliği ve geçerliği. Türk Psikoloji Dergisi, 7, 10-16. https://doi.org/10.1501/kriz_0000000309

Dağ, İ. (2002). Kontrol Odağı Ölçeği: Ölçek geliştirme, güvenirlik ve geçerlik çalışması. Türk Psikoloji Dergisi, 17, 77-90. https://doi.org/10.18656/jee.22471

Dirkzwager, A. J. E., Bramsen, I., \& van der Ploeg, H. M. (2003). Social support, coping, life events, and posttraumatic stress symptoms among former peacekeepers: a prospective study. Personality and Individual Differences, 34, 1545-1559. https://doi.org/10.1016/s0191-8869(02)00198-8

DSM-IV \& APA. (1994). Diagnostic and statistical manual of mental disorders. Washington, DC: APA. https://doi.org/10.1017/s0033291700035765

DSM-V \& APA. (2013). Diagnostic and statistical manual of mental disorders (5th ed.). Washington, DC: APA. https://doi.org/10.1108/rr-10-2013-0256

Durak, B. A. (1994). Beck umutsuzluk ölçeği'nin geçerlik ve güvenirlik çalışması. Türk Psikoloji Dergisi, 9(31), 1-11. https://doi.org/10.1501/kriz_0000000244

Dürü, Ç. (2006). Travma sonrası stres belirtileri ve travma sonrası büyümenin çeşitli değişkenler açısından incelenmesi ve bir model önerisi. Yayımlanmamış Doktora Tezi. Hacettepe Üniveristesi, Sosyal Bilimler 
Enstitüsü, Ankara. https://doi.org/10.29029/busbed.494469

Eker, D., Arkar, H., \& Yaldız, H. (1995). Çok boyutlu algılanan sosyal destek ölçeği'nin gözden geçirilmiş formunun faktör yapıs1, geçerlik ve güvenirliği. Türk Psikiyatri Dergisi, 11, (1) 17-25. https://doi.org/10.1501/0000861

Erkaya, H. (2003). Acil kurtarma ekiplerinde travma sonrası stres bozukluğu. Yayınlanmamış tıpta uzmanlık tezi. Osmangazi Üniversitesi Sağlık Bilimleri Enstitüsü, Eskişehir.

Foa, E. B., Cashman, L., Jaycox, L., \& Perry, K. (1997). The validation of a self-report measure of posttraumatic stress disorder: The Posttraumatic Diagnostic Scale. Psychological Assessment, 9(4), 445-451. https://doi.org/10.1037//1040-3590.9.4.445

Fullerton, C. S., Ursano, R. J., \& Wang, L. (2004). Acute stress disorder, posttraumatic stress disorder, and depression in disaster or rescue workers. American Journal of Psychiatry, 161(8), 1370-1376. https://doi.org/10.1176/appi.ajp.161.8.1370

Harvey, M. R. (1996). An ecological view of psychological trauma and trauma recovery. Journal of Traumatic Stress, 9, 3-23.

Heppner, P. P., \& Petersen, C. H. (1982). The development and implications of a personal problem solving inventory. Journal of Counseling Psychology, 29, 66-75. https://doi.org/10.1037//0022-0167.29.1.66

Hisli, Ş. (1988), Beck depresyon envanterinin üniversite ögrencileri için geçerliği ve güvenilirligi. Psikoloji Dergisi, 22, 118-126.

Horowitz, M. J., Wilner, N., \& Alvarez, W. (1979). Impact of event scale: A measure of subjective stress. Psychosomatic Medicine, 41(3), 209-218. https://doi.org/10.1097/00006842-197905000-00004

Hyman, J. (2004). Lacking balance?: Work - life employment practices in the modern economy. Personnel Review, 33(4), 418-429. https://doi.org/10.1108/00483480410539498

Işıklı, S. (2006). Travma sonrası stres belirtileri olan bireylerde olaya ilişkin dikkat yanlıllğ̆l, ayrlşma düzeyi ve çalışma belleği uzamı arasındaki iliş̧iler. Yayımlanmamış doktora tezi, Hacettepe Üniversitesi Sosyal Bilimler Enstitüsü, Ankara.

Janoff-Bulman, R. (2004). Posttraumatic growth: Three explanatory models. Psychological Inquiry, 15(1), 30-34.

Johnson, J. E., Jasmine, S. S., Kozak, M. L., \& Johnson, F. B. (2008). In vivo veritas: using yeast to probe the $\begin{array}{llll}\text { biological functions of } & \text { G-quadruplexes. Biochimie, }\end{array}$ https://doi.org/10.1016/j.biochi.2008.02.013

Jonsson, J. E., \& Halabi, A. (2006). Work related post-traumatic stress as described by Jordanian emergency nurses. Accident and Emergency Nursing, 14(2), 89-96. https://doi.org/10.1016/j.aaen.2006.02.001

Joseph, S., \& Williams, R. (2005). Understanding posttraumatic stress: Theory, reflections, context and future. Behavioural and Cognitive Psychotherapy, 33(4), 423-441. https://doi.org/10.1017/s1352465805002328

Kahil, A. (2016). Travmati yaşantılar olan bireylere yardım davranışlarında bulunan profesyonel ve gönüllülerin ikincil travmatik stres düzeylerinin incelenmesi. Yayımlanmamış yüksek lisans tezi. Ufuk Üniversitesi Sosyal Bilimler Enstitüsü, Ankara. https://doi.org/10.17218/husbed.87035

Karanc1, A. N., Alkan, N., Akşit, B., Sucuoğlu, H., \& Balta, E. (1999). Gender differences in psychological distress, coping, social support and related variables following the 1995 Dinar (Turkey) earthquake. North American Journal of Psychology, 1(2), 189-204.

Karasar, N. (2013). Bilimsel Araştırma Yöntemi. Ankara: Nobel Akademik Yayıncılık.

Koren, D., Arnon, I., \& Klein, E. (1999). Acute stress response and posttraumatic stress disorder in traffic accident victims: A one-year prospective, follow-up study. American Journal of Psychiatry, 156(3), 367-373.

Lee, D., \& Young, K. (2001). Post-traumatic stress disorder: Diagnostic issues and epidemiology in adult survivors of traumatic events. International Review of Psychiatry, 13(3), 150-158. https://doi.org/10.1080/09540260120074000

Lundin, T., \& Bodegard, M. (1993). The psychological impact of an earthquake on rescue workers: A follow-up study of the Swedish group of rescue workers in Armenia. Journal of Traumatic Stress, 6(1), 129-139. https://doi.org/10.1002/jts.2490060111 
Maercker, A., \& Herrle, J. (2003). Long-term effects of the Dresden bombing: Relationships to control beliefs, religious belief, and personal growth. Journal of Traumatic Stress, 16(6), 579-587. https://doi.org/10.1023/B:JOTS.0000004083.41502.2d

Marmar, C. R., Weiss, D. S., \& Metzler, T. J. (1997). The peritraumatic dissociative experiences questionnaire. In J. P. Wilson, \& T. M. Keane (Eds.), Assessing psychological trauma and PTSD. New York: Guilford Press. https://doi.org/10.1037/t07470-000

Marshall, G. N., Orlando, M., Jaycox, L. H., Foy, D. W., \& Belzberg, H. (2002). Development and validation of a modified version of the peritraumatic dissociative experiences questionnaire. Psychological Assessment, 14(2), 123-134. https://doi.org/10.1037//1040-3590.14.2.123

North, C. S., Tivis, L., McMillen, J. C., Pfefferbaum, B., Spitznagel, E. L., Cox, J., ... Smith, E. M. (2002). Psychiatric disorders in rescue workers after the Oklahoma City Bombing. Am J Psychiatry, 159(5), 857-869. https://doi.org/10.1176/appi.ajp.159.5.857

Park, C. L., Cohen, L. H., \& Murch, R. (1996). Assessment and prediction of stress related growth. Journal of Personality, 64(1), 71-105. https://doi.org/10.1111/j.1467-6494.1996.tb00815.x

Pengilly, J. W., \& Dowd, E. T. (2000). Hardiness and social support as moderators of stress. Journal of Clinical Psychology, 56(6), 813-820. https://doi.org/10.1002/(SICI)1097-4679(200006)56:6<813::AID-JCLP10>3.0. $\mathrm{CO} ; 2-\mathrm{Q}$

Reynolds, M., \& Brewin, C. R. (1998). Intrusive memories in depression and posttraumatic stress disorder. Behaviour Research and Therapy, 37(3), 201-215. https://doi.org/10.1016/S0005-7967(98)00132-6

Rotter, J. B. (1966). Generalized expectancies for internal vs external control of reinforcement. Psychological Monographs, 80(1), 1-28. https://doi.org/10.1037/h0092976

Sabin-Farrell, R., \& Turpin, G. (2003). Vicarious traumatization: Implications for the mental health of health workers? Clinical Psychology Review, 23(3), 449-480. https://doi.org/10.1016/S0272-7358(03)00030-8

Şahin, N., Şahin, N. H., \& Heppner, P. P. (1993). Psychometric properties of the Problem Solving Inventory in a group of Turkish university students. Cognitive Therapy and Research, 17(4), 379-396. https://doi.org/10.1007/BF01177661

Sarason, L. G., Sarason, B. R., Pierce, G. R., \& Shearin, E. N. (1987). Interrelations of social support measures: Theoretical implications. Journal of Personality and Social Psychology, 52(4), 813-832. https://doi.org/10.1037//0022-3514.52.4.813

Savaşır, I., \& Şahin, N. H. (1997). Bilişsel-davranışçı terapilerde değerlendirme: Sık kullanılan ölçekler. Ankara: Türk Psikologlar Derneği Yayınları.

Schnurr, P. P., Lunney, C. A., \& Sengupta, A. (2004). Risk factors for the development versus maintenance of posttraumatic stress disorder. Journal of Traumatic Stress, 17(2), 85-95. https://doi.org/10.1023/b:jots.0000022614.21794.f4

Seber, G. (1991). Beck Umutsuzluk Ölçeği'nin geçerlik ve güvenirliği üzerine bir çalışma. Yayınlanmamış Doçentlik Tezi. Anadolu Üniversitesi Tıp Fakültesi, Psikiyatri Bölümü, Eskişehir.

Seber, G., Dilbaz, N., Kaptanoğlu, C., \& Tekin, D. (1993). Umutsuzluk Ölçeği: Geçerlilik ve güvenirliği. Kriz Dergisi, 1(3) 139-142. https://doi.org/10.1501/kriz_0000000045

Solomon, Z., Mikulincer, M., \& Avitzur, E. (1988). Coping, locus pf control, social support, and combat related posttraumatic stress disorder: A prospective study. Journal of Personality and Social Psychology, 55(2), 279-285. https://doi.org/10.1037//0022-3514.55.2.279

Sönmez, S. (2006). Filmlerle Hatırlamak. Toplumsal travmaların sinemada temsil edilişi. Metis yayınları İstanbul. https://doi.org/10.31122/sinefilozofi.421771

Taylor, S., Kuch, K., Koch, W. J., Crockett, D. J., \& Passey, G. (1998). The structure of posttraumatic stress $\begin{array}{lllll}\text { symptoms. Journal of Abnormal Psychology, 107(1), } & \text { 154-160. }\end{array}$ https://doi.org/10.1037//0021-843x.107.1.154

Tedeschi, R. G., \& Calhoun, L. G. (1996). The post-traumatic growth inventory: Measuring the positive legacy of trauma. Journal of Traumatic Stress, 9, 455-471. https://doi.org/10.1002/jts.2490090305

Tedeschi, R. G., \& Calhoun, L. G. (2004). Posttraumatic growth: Conceptual foundations and empirical evidence. Psychological Inquiry, 15(1), 1-18. https://doi.org/10.1207/s15327965pli1501_01 
Türksoy, N. (2003). Psikolojik travma ve tanım sorunları. Psikolojik travma ve sonuçları, 1. Baskı, T. Aker, M. E. Önder (Eds), 5 US Yayınları, İstanbul.

Zimet, G. D., Dahlen, N. M., Zimet, S. G., \& Farley, G. K. (1988). The multidimensional scale of perceived social support. Journal of Personality Assessment, $52(1), \quad 30-41$. https://doi.org/10.1207/s15327752jpa5201_2

\section{Copyrights}

Copyright for this article is retained by the author(s), with first publication rights granted to the journal.

This is an open-access article distributed under the terms and conditions of the Creative Commons Attribution license (http://creativecommons.org/licenses/by/4.0/). 